\title{
Kompetensi Pustakawan IAIN Kudus dan UIN Walisongo Semarang dalam penulisan karya ilmiah
}

\author{
Wiji Suwarno ${ }^{*}$ \\ anstitut Agama Islam Negeri Salatiga
}

\begin{abstract}
Abstrak
Menulis adalah aktivitas dalam rangka diseminasi informasi yang pada umumnya dilakukan oleh fungsional dosen, yang secara tupoksi sudah menjadi kewajibannya untuk menghasilkan karya ilmiah sebagaimana diatur dalam Permenristekdikti No. 20 Tahun 2017. Pada konteks aktivitas dan rutinitas kepustakawanan, di Indonesia khususnya pada Perguruan Tinggi Keagamaan Islam Negeri (PTKIN), telah muncul sejumlah jurnal bidang Ilmu Perpustakaan dan Informasi sebagai tanda bergeliatnya pustakawan dalam urusan kepenulisan, baik yang diterbitkan oleh asosiasi kepustakawan atau oleh lembaga pendidikan pemerintah. Penelitian ini mengambil tema mengenai kesulitan yang dihadapi pustakawan dalam menyusun karya tulis. Karya tulis ini bertujuan untuk berupaya menemukan fakta-fakta kompetensi pustakawan dalam menulis di era sekarang, dan mengungkap kesulitan yang dihadapi pustakawan dalam memproduksi karya tulis dilihat dari faktor pendukung maupun dari faktor hambatan pustakawan dalam menulis. Penelitian ini menggunakan jenis penelitian kualitatif, dengan pendekatan fenomenologi. Analisis data yang digunakan dalam penelitian ini adalah eksploratif-deskriptif, yaitu mengeksplorasi pendapat, tanggapan, usulan dari berbagai pihak, serta mendeskripsikan hasil pengumpulan data yang didapat dari informan. Pengumpulan data dilakukan dengan wawancara, observasi dan dokumentasi. Informan diambil dari unsur pustakawan yang kemudian disebut sebagai subjek penelitian dari IAIN Kudus dan UIN Walisongo Semarang. Hasil penelitian ini adalah bahwa kompetensi menulis pustakawan PTKIN (Perguruan Tinggi Keagamaan Islam Negeri) sudah merambah pada dunia publikasi baik tercetak maupun virtual, kedua daya dukung kompetensi menulis bergantung pada daya dukung kulutural dan struktural serta hambatan pustakawan dalam menulis adalah kekhawatiran plagiat, kurangnya aktivitas membaca, kesulitan menentukan topik, malas, minimnya referensi yang dikuasai, serta angka kredit yang rendah.
\end{abstract}

Kata kunci: Kesulitan menulis; Produktivitas menulis; Publikasi ilmiah; Pustakawan PTKIN

Korespondensi: Wiji Suwarno, IAIN Salatiga, Jl. Lkr. Sel. Salatiga KM 2, Jawa Tengah 50716, Indonesia

Email: wiji.suwarno@gmail.com

http://jurnal.unpad.ac.id/informatio

DOI: https://doi.org/10.24198/inf.v1i2.34371

Received: Juni 2021; Accepted: Juli 2020; Published: Juli 2021

(C) Informatio 2021. This is an open access article under the CC BY-SA license 


\title{
Competencies of LAIN Kudus and UIN Walisongo Semarang Librarians in writing scientific papers
}

\begin{abstract}
Writing is an activity in the context of information dissemination which is generally carried out by functional lecturers, whose main duties and responsibilities are to produce scientific works as regulated in Permenristekdikti No. 20 of 2017. In the context of librarianship activities and routines, in Indonesia, especially at the State Islamic Religious University (PTKIN), several journals in the field of Library and Information Sciences have emerged as a sign of the librarian's involvement in writing matters, whether published by librarian associations or by other institutions. government education. This study takes the theme of the difficulties faced by librarians in compiling written works. This paper aims to seek to find facts about the competence of librarians in writing in the current era and to reveal the difficulties faced by librarians in producing written works in terms of supporting factors and obstacles to librarian writing. This study uses a qualitative research type, with a phenomenological approach. The data analysis used in this research is exploratory-descriptive, namely exploring opinions, responses, proposals from various parties, and describing the results of data collection obtained from informants. Data collection was done by interview, observation, and documentation. Informants were taken from elements of librarians who were later referred to as research subjects from IAIN Kudus and UIN Walisongo Semarang. The results of this study are that the writing competence of PTKIN (State Islamic Religious College) librarians has penetrated the world of publications, both printed and virtual, both the carrying capacity of writing competence depends on the cultural and structural support capacity and the obstacles for librarians in writing are concerns of plagiarism, lack of reading activity, difficulty determining topics, laziness, lack of mastered references, and low credit scores.
\end{abstract}

Keywords: Writing difficulties; Writing productivity; Scientific publications; PTKIN librarian

\section{PENDAHULUAN}

Pada era digital sebagaimana kondisi sekarang ini, berbagai jenis informasi muncul begitu cepat. Sulit untuk diprediksi berapa kuantitas dan bagaimana kualitas informasi yang terlahir. Uniknya di era sekarang adalah informasi ini mampu mempengaruhi pola hidup, bahkan hampir semua aspek kehidupan. Karenanya, masing-masing individu sebenarnya dituntut untuk mampu memilih informasi yang tepat, sehingga akurasi dari analisa informasi yang dilakukan akan menjadi penentu keberhasilan, tidak saja bagi individu tapi juga bisa untuk kelompok (Lopatina, 2014, p. 155).

Secara khusus penulisan ini menyebut pustakawan PTKIN (Perguruan Tinggi Keagamaan Islam Negeri) yang berposisi sebagai target sebagai informan, secara kuantitatif berlum menyebar secara merata. Berikut dapat dilihat sebaran pustakawan di PTKIN, berdasar data APPTIS Tahun 2020, sebagai berikut. 


\begin{tabular}{|c|c|c|c|c|c|c|c|c|c|c|c|c|c|}
\hline \multirow[t]{2}{*}{ No } & \multirow[t]{2}{*}{ PTKIN } & & \multicolumn{3}{|c|}{ Data Pustakawan } & \multicolumn{3}{|c|}{ Pustakawan terampil } & \multicolumn{3}{|c|}{ Pustakawan } & & \multirow[t]{2}{*}{ Total } \\
\hline & & Dip & S1 & S2 & S3 & PL & PLJ & PYL & Pertama & Muda & Madya & Utama & \\
\hline 1 & $\begin{array}{l}\text { UIN Sunan } \\
\text { Ampel } \\
\text { Surabaya }\end{array}$ & & 5 & 9 & & & & 3 & & 5 & 5 & 1 & 14 \\
\hline 2 & $\begin{array}{c}\text { UIN Syarif } \\
\text { Hidayatulla } \\
\text { h Jakarta }\end{array}$ & 1 & 13 & 4 & 2 & & & 1 & 5 & 6 & 8 & & 20 \\
\hline 3 & $\begin{array}{l}\text { UIN Sunan } \\
\text { Kalijaga } \\
\text { Yogyakarta }\end{array}$ & & 10 & 7 & & & & & 4 & 6 & 7 & & 17 \\
\hline 4 & $\begin{array}{c}\text { UIN } \\
\text { Mataram }\end{array}$ & & 9 & 1 & & & & & 6 & 3 & 1 & & 10 \\
\hline 5 & $\begin{array}{c}\text { UIN Ar- } \\
\text { Raniry Aceh }\end{array}$ & & 9 & 4 & & & & 1 & 3 & 2 & 7 & & 13 \\
\hline 6 & $\begin{array}{l}\text { UIN Raden } \\
\text { Falah } \\
\text { Palembanq }\end{array}$ & 1 & 2 & 5 & & & & 1 & & 4 & 3 & & 8 \\
\hline 7 & $\begin{array}{c}\text { UIN } \\
\text { Sumatera } \\
\text { Utara }\end{array}$ & & 7 & 2 & & & & & 3 & 4 & 2 & & 9 \\
\hline 8 & $\begin{array}{l}\text { UIN Sultan } \\
\text { Syarif } \\
\text { Qastm Riau }\end{array}$ & 2 & 11 & 2 & 2 & 1 & 1 & & 4 & 7 & 4 & & 17 \\
\hline 9 & $\begin{array}{c}\text { UIN } \\
\text { Maulana } \\
\text { Malik } \\
\text { Ibrahim }\end{array}$ & & 1 & 3 & & & & 1 & & 1 & 2 & & 4 \\
\hline 10 & $\begin{array}{c}\text { UIN } \\
\text { Alauddin } \\
\text { Makassar }\end{array}$ & & 3 & 4 & & & & & 1 & 3 & 3 & & 7 \\
\hline 11 & $\begin{array}{c}\text { UIN STS } \\
\text { Jambi }\end{array}$ & & 4 & 3 & & & & & & 5 & 2 & & 7 \\
\hline
\end{tabular}


UIN Sunan

12 Gunung

Djati,

$13 \quad 3$

6

3

16

Bandung

UIN

13 Walisongo

14

5

Semarang

UIN Raden

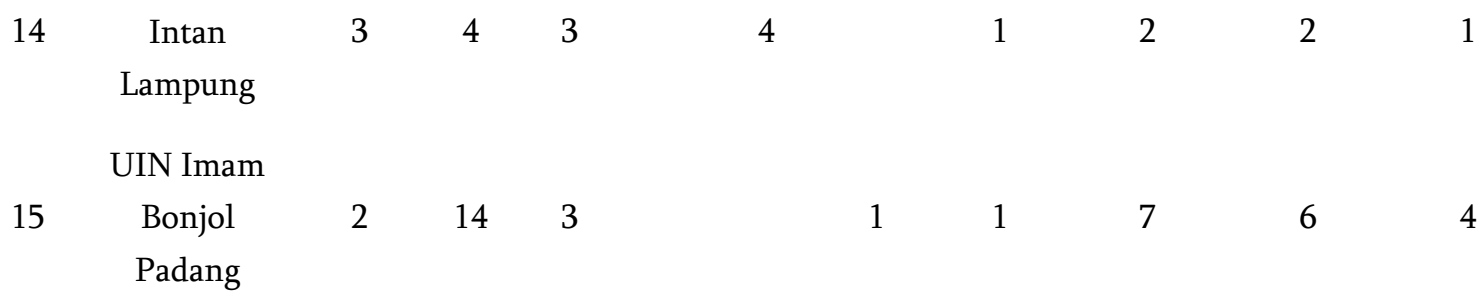

UIN Sultan

16 Maulana

Hasanuddin

2

2

Banten

UIN

17 Antasa

Banjarmasin

18 IAIN

$3 \quad 1$

1

2

4

$19 \begin{gathered}\text { IAIN } \\ \text { Surakarta }\end{gathered}$

24

2

6

20 IAIN

Purwokerto

22

2

4

21 IAIN

Samarinda

35

5

8

$22 \underset{\text { IAIN }}{\text { Pontianak }} \quad 1$

IAIN

23

Palangkaray

24

IAIN

Jember

21

2

2

$25 \quad \begin{gathered}\text { IAIN } \\ \text { Bukittinggi }\end{gathered}$

1

1

1

26

$\begin{array}{lll}\text { IAIN } & 1 & 3\end{array}$

2

1 
Batusangkar

IAIN

27

Padangside

1

1

1

mpuan

28 IAIN Langsa

29 IAIN

Ambon

1

1

1

IAIN

$30 \quad$ Tulung

$4 \quad 1$

2

3

5

Agung

31 IAIN

32 IAIN

Gorontalo

33 IAIN Palopo

34 IAIN

Manado

1

1

1

35 IAIN

Kendari

31

3

4

36 IAIN Palu

3

3

$37 \begin{gathered}\text { IAIN } \\ \text { Pekalongan }\end{gathered}$

2

IAIN Syekh

$38 \quad$ Nuriati

4

Cirebon

39

$\begin{array}{llll}\text { IAIN } & 1 & 3 & 4\end{array}$

$\begin{array}{llll}40 & \text { IAIN } & 2 & 2\end{array}$

41 IAIN Métro

7

1

3

3

7

$42 \quad \begin{array}{ll}\text { STAIN } \\ \text { Kerinci }\end{array}$

2

8

8

$43 \quad \begin{array}{ll}\text { STAIN } \\ \text { Kudus }\end{array}$

3

1

4

$\begin{array}{rrrrrrrrr}\text { STAIN } & 2 & 8 & 3 & 2 & 4 & 4 & 3\end{array}$

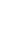


IAIN

Malikussale

45 $\mathrm{h}$ $2 \quad 1$ 3

Lhoksemaw

e

46 STAIN

47 IAIN Bone

Watampone

\section{STAIN SAS}

48

Bangka

Belitung

STAIN
Pare-Pare

15

5

STAIN
Pamekasan

1

1

1

51 STAIN

Curup

$4 \quad 2$

2

2

6

STAIN

52 Gajah Putih

Takengon

53

STAIN

Sorong

$54 \quad$ STAIN

IAIN Al-

55 Fattah

Jayapura

56

STAIN

Majene

STAIN

Sultan

57

Abdurrahm

an

Kepulauan

Riau

JUMLAH

TOTAL 
Dari tabel ini bisa dilihat sebaran pustakawan yang tidak merata, dan tidak berimbang antara PTKIN yang besar dengan PTKIN yang masih dalam kategori sekolah tinggi. Data ini ditampilkan sebagai titik perhatian bahwa sebaran pustakawan PTKIN yang tidak merata, akan dilihat dari sudut pandang produktivitas menulisnya secara kualitatif. Pustakawan sudah saatnya memiliki kompetensi yang sepadan dengan kondisi perkembangan. Jika meminjam istilahmya Patric M. Wright, bahwa pustakawan era milenial sekarang ini diharapkan memiliki keunggulan kompetitif (Wright et al., 1994, p. 5) yaitu kompetensi yang dikembangkan dari kompetensi standar yang dimiliki pustakawan sebagaimana aturan yang ada pada jenjang Jabatan Fungsional Pustakawan berikut Angka Kreditnya. Peraturan ini dapat dikatakan sebagai dasar gerak pustakawan dalam melaksanakan tugas sehari-harinya dalam konteks sebagai suatu profesi.

Menulis bagi jabatan fungsional pustakawan dapat dikatakan adalah suatu kemampuan yang unik. Mengapa demikian, karena pustakawan dalam rentang waktu puluhan tahun bahkan sampai sekarang masih ada pemikiran yang mendudukkan pustakawan hanya sebagai pekerja technical, dan cenderung pada pekerjaan yang administratif. Padahal jika menengok pada juknisnya, pustakawan mempunyai fungsi sekaligus tugas pengembangan profesi yakni dapat menghasilkan karya tulis (D. R. Indonesia, 2014).

Kepenulisan tercantum dalam butir kegiatan pustakawan masuk dalam unsur utama penilaian angka kredit. Hal ini diatur dalam permenpan No. 09 Tahun 2014. Dipahami di sini bahwa pustakawan memiliki tugas lainnya selain bersifat teknis yaitu dalam hal menulis. Foster melihat jika kegiatan menulis ini menjadi salah satu teknik dalam rangka menyampaikan gagasan kepada orang lain melalui media tulisan (Foster, 2005, p. 1). Data PDIII LIPI menginformasikan bahwa terdapat lima belas media penulisan (jurnal) bertema ilmu perpustakaan dan informasi yang diterbitkan oleh PTKIN. Jika diasumsikan sekali terbit satu jurnal menayangkan enam artikel, maka ini artinya dapat diprediksi terdapat lebih dari sembilan puluh artikel yang dapat dipublikasikan per-edisi.

Pengelola jurnal seringkali mengeluhkan kesulitan mendapatkan naskah artikel untuk tertib terbit. Oleh karena secara kuantitas artikel yang masuk tidak memenuhi target minimal untuk diterbitkan, sebenarnya ini menjadi peluang bagi pustakawan berkreasi, mengirimkan tulisan ke jurnal-jurnal bidang kepustakawanan itu. Titik masalah penelitian yaitu pada profesi pustakawan yang bekerja di lingkungan PTKIN yang masih minimalis dalam menghasilkan karya tulis, sementera media publikasi bidang ilmu perpustakaan dan informasi sudah mulai bermunculan. Karya tulis ilmiah adalah karya yang berbentuk teks (tulisan) dengan berbagai permasalahan yang diselidiki, diamati, dikumpulkan berbagai data dalam satu storage yang diperoleh dari penelitian, yang kemudian dibahas dengan beragam analisa sehingga diperoleh suatu kesimpulan sebagai hasil akhirnya (INDONESIA, 2008, p. 5). 
Karya tulis ilmiah menjadi implementasi dari kegiatan ilmiah yang disampaikan melalui bahasa tulisan. Karya tulis ilmiah ini mempunyai kekuatan dalam menyajikan fakta. Oleh sebab suatu tulisan dapat dikatakan ilmiah jika memuat ide atau pemikiran yang disampaikan secara logis, dapat dibuktikan kebenarannya serta mematuhi sistematika standar tulisan karya ilmiah. Pada prosesnya menulis harus melalui pertimbangan tujuan penulisan, siapa yang akan menjadi pembacanya, memiliki gagasan, memilih cara penyelesaian masalah, membuat draft atau konsep sampai pada tahap menulis dan evaluasi. Pada tahap evaluasi ini termasuk di dalamnya adalah meneliti tulisan dan tata tulis lainnya (Kirszner \& Mandell, 2008, p. 29).

Ruang lingkup penelitian ini adalah pada sumber daya manusia di lembaga informasi yaitu pada perpustakaan, dengan fokus perhatian pada kompetensi yang tercantum dalam Permenpan RB Nomor 09 Tahun 2014 yang mengatur tentang kompetensi kepenulisan. mempertimbangkan karya sudah ada, dan dari penelitian yang sudah dilakukan sebagaimana pada kajian pustaka, penulisan ini mengambil sisi yang berbeda yaitu pertama, subjek penelitian pada penelitian sebelumnya adalah pada pembelajar, siswa atau peserta pelatihan, untuk penelitian ini adalah pustakawan, dimana secara akademis sudah menyelesaikan tahapan studi formalnya. Kedua, objek penelitian ini adalah pada keengganan pustakawan dalam menyusun karya tulis ilmiah atau permasalahan yang dihadapi pustakawan dalam menulis, tidak melihat pada ranah teknis penulisan sebagaiman yang dilihat pada penelitian sebelumnya.

Menulis adalah aktivitas dalam rangka diseminasi informasi yang pada umumnya dilakukan oleh fungsional dosen, yang secara tupoksi sudah menjadi kewajibannya untuk menghasilkan karya ilmiah sebagaimana diatur dalam Permenristekdikti No. 20 Tahun 2017. Pada konteks aktivitas dan rutinitas kepustakawanan, di Indonesia khususnya pada Perguruan Tinggi Keagamaan Islam Negeri (PTKIN), telah muncul sejumlah jurnal bidang Ilmu Perpustakaan dan Informasi sebagai tanda bergeliatnya pustakawan dalam urusan kepenulisan, baik yang diterbitkan oleh asosiasi kepustakawan atau oleh lembaga pendidikan pemerintah.

Tentu saja hal ini dapat dibaca sebagai isyarat mulainya muncul perhatian dari pemerintah maupun asosiasi terkait dengan publikasi karya ilmiah ini. Ini berarti pula pustakawan di PTKIN maupun di Indonesia pada umumnya telah memperlihatkan kepada dunia bahwa pustakawan mempunyai kompetensi juga dalam menulis. Melihat data yang dimiliki oleh PDII-LIPI, bahwa lembaga atau asosiasi yang mengajukan permohonan penerbitan ISSN, diperoleh informasi bahwa terdapat sejumlah terbitan berkala yang sudah terdaftar dan mendapatkan ISSN, yaitu: 
Tabel 2. Daftar Terbitan Berkala Online Tahun 2017

\begin{tabular}{cc} 
NO & NAMA TERBITAN BERKALA \\
\hline 1 & ACARYA PUSTAKA: Jurnal Ilmiah \\
& Perpustakaan dan Informasi \\
2 & Al-KUTTAB: Jurnal Perpustakan dan \\
& Informasi
\end{tabular}

3 AL-MAKTABAH: Jurnal Komunikasi dan Informasi Perpustakaan
(https://ejournal.undiksha.ac.id/index.php/AP/ index)
(http://e-

URL

ANUVA: Jurnal Kajian Budaya, Perpustakaan, dan Informasi

journal.perpustakaanstainpsp.net/index.php/al kuttab)
(http://journal.uinjkt.ac.id/index.php/al- maktabah)
(https://ejournal2.undip.ac.id/index.php/anuva /index)

4

5

BACA: Jurnal Dokumentasi dan Informasi
BIBLIOTIKA :Jurnal Kajian
Perpustakaan dan Informasi
ala Ilmu Perpustakaan dan Informasi

6 Informasi
BIBLIOTIKA :Jurnal Kajian
Perpustakaan dan Informasi
IImu Perpustakaan dan Informasi Informasi
BIBLIOTIKA :Jurnal Kajian
Perpustakaan dan Informasi
IImu Perpustakaan dan Informasi $\begin{array}{cc} & \text { Informasi } \\ 6 & \text { BIBLIOTIKA :Jurnal Kajian } \\ & \text { Perpustakaan dan Informasi } \\ 7 & \text { Berkala Ilmu Perpustakaan dan Informasi }\end{array}$

(http://journal2.um.ac.id/index.php/bibliotika)

(http://jurnalbaca.pdii.lipi.go.id)

6 (https://jurnal.ugm.ac.id/bip/index)

8 EDULIB: Journal of Library and Information Science

9 FIHRIS: Jurnal Bidang Kajian Perpustakaan

10 IQRA': Jurnal Perpustakaan dan
Informasi JIPI: Jurnal Ilmu Perpustakaan dan
Informasi Journal of Documentation and Information Science

13 JUPITER (Jurnal Perpustakaan Informasi dan Komputer)

14 Jurnal GEMA Pustakawan (http://ejournal.upi.edu/index.php/edulib)

\author{
(http://ejournal.uin- \\ suka.ac.id/adab/FIHRIS/index) \\ (http://jurnal.uinsu.ac.id/index.php/iqra) \\ (http://jurnal.uinsu.ac.id/index.php/jipi) \\ (http://jodis.isipii.org/index.php/jodis)
}

(http://journal.unhas.ac.id/index.php/jupiter)

(https://ejournal.unri.ac.id/index.php/JGP)

15 Jurnal Ilmu Informasi, Perpustakaan, dan (http://jipi-ui.web.id/index.php/jipk) 
16

Jurnal IPI (Ikatan Pustakawan Indonesia)

17

18

19

20

21

22

23

24

25

26

27

28

29

30

31

32

Jurnal Imam Bonjol : Kajian Ilmu Informasi dan Perpustakaan

Jurnal Kajian Informasi dan

Perpustakaan

Jurnal Palimpsest

Jurnal PARI

Jurnal Pustaka Ilmiah

Jurnal Perpustakaan Pertanian

Jurnal Perpustakaan Universitas

Airlangga

Jurnal Pustaka Nusantara dan Budaya

Jurnal Pustakawan Indonesia

Jurnal Ilmu Informasi Perpustakaan dan Kearsipan

KHIZANAH AL-HIKMAH: Jurnal Ilmu Perpustakaan, Informasi, dan Kearsipan

LENTERA PUSTAKA: Jurnal Kajian Ilmu Perpustakaan, Informasi, dan Kearsiapan

LIBRARIA: Jurnal Perpustakaan

LIBRIA : Library of UIN Ar-Raniry

Majalah Librisyiana

Media Pustakawan (http://ipi.web.id/jurnal/)

(https://journal.pustakauinib.ac.id/index.php/ji

b)

(http://jurnal.unpad.ac.id/jkip)

(http://journal.unair.ac.id/media_86.html)

(http://ejournal-

balitbang.kkp.go.id/index.php/JP)

(http://journal.library.uns.ac.id/index.php/jpi)

(http://ejurnal.litbang.pertanian.go.id/index.ph $\mathrm{p} / \mathrm{jpp})$

(http://journal.unair.ac.id/JPUA@jurnalperpustakaan-universitas-airlangga-media162.html)

(https://jurnal.usu.ac.id/index.php/jpn/index)

(http://journal.ipb.ac.id/index.php/jpi)

(http://ejournal.unp.ac.id/index.php/iipk/index (http://journal.uinalauddin.ac.id/index.php/khizanah-al-hikmah)

(http://ejournal.undip.ac.id/index.php/lpustaka (http://journal.stainkudus.ac.id/index.php/Libr aria)

(http://jurnal.ar-raniry.ac.id/index.php/libria)

(http://library.unsyiah.ac.id/majalahlibrisyiana-edisi-i-oktober-2015/\#)

(http://pustakawan.perpusnas.go.id/media; http://pustakawan.perpusnas.go.id/jurnal/inde 
x.php)

33

34

35

36

37

38

39

40
Paradigma : Jurnal Kajian Budaya

PUBLIS Journal

PUSTABIBLIA: Journal of Library and Information Science

PUSTAKALOKA: Jurnal Kajian Informasi dan Perpustakaan

Record and Library Journal

SHAUT AL-MAKTABAH: Jurnal Perpustakaan, Arsip, dan Dokumentasi

TIK ILMEU: Jurnal IImu Perpustakaan dan Informasi

Visi Pustaka: Buletin Jaringan Informasi Antar Perpustakaan (http://paradigma.ui.ac.id/index.php/paradigm

a)

(http://journal.umpo.ac.id/index.php/PUBLIS)

(http://e-

journal.iainsalatiga.ac.id/index.php/pustabiblia

)

(http://jurnal.stainponorogo.ac.id/index.php/p ustakaloka)

(http://e-journal.unair.ac.id/index.php/RLJ)

(http://ejournal.uinib.ac.id/index.php?journal= sam)

(http://journal.staincurup.ac.id/index.php/TI)

(http://www.perpusnas.go.id/magazine.php?la ng=id\&id=Visi\%20Pustaka)

Sumber: Pengolahan data oleh Peneliti (2017)

Penerbitan media bidang perpustakaan ini adalah bentuk perkembangan positif kepustakawanan yang memacu para pustakawan untuk menulis. Jurnal ilmu perpustakaan memberikan wadah bagi pustakawan untuk curah gagasan, berbagi ide, bertukar pengetahuan dan lain-lain melalui media ini. Seiring dengan perkembangan teknologi, publikasi ilmiah inipun memasuki era publikasi online, meskipun publikasi yang printed pun masih diberlakukan.Kreatifitas berfikir manusia berpengaruh terhadap dinamisnya peradaban. Peradaban akan senantiasa berkembang dan memiliki perbedaan secara historis karena pemikiran manusia yang juga berkembang mengikuti kebutuhan dan tuntutan keadaan termasuk keadaan dalam menghadapi berbagai macam persoalan keilmuan.

Penulisan karya ilmiah merupakan salah satu syarat yang harus dipenuhi oleh pustakawan dalam karirnya pada jabatan profesi. Hal ini diatur dalam Peraturan Menteri Pendayagunaan Aparatur Negara dan Reformasi Birokrasi (Permenpan RB) Nomor 09 Tahun 2014 sebagaimana disampaikan sebelumnya bahwa kenaikan pangkat dalam jabatan fungsional pustakawan mulai dari golongan ruang III/b ke atas sampai dengan IV/e, terdapat persyaratan minimal dalam pengajuan angka kredit berasal dari sub unsur 
pengembangan profesi. Unsur pengembangan profesi tersebut adalah meliputi pembuatan karya tulis/ karya ilmiah di bidang kepustakawanan. Karya ilmiah adalah tulisan hasil pokok pikiran, pengembangan, dan hasil kajian/ penelitian bidang kepustakawanan yang disusun oleh pustakawan baik perorangan maupun kelompok.

Derrida, lengkapnya Jacques Derrida, seorang filsuf dari Aljazair memperkenalkan teori dekonstruksi dengan membuka perspektif bahwa pengetahuan itu sifatnya dekonstruktir, yakni mengurai, membongkar, dan membuka(Maksum, 2008, p. 331) pengetahuan yang sudah ada, sehingga diperoleh pengetahuan yang baru setelah mempelajari pengetahuan sebelumnya. Kemunculan teori dekonstruksi ini menjadi perlawanan bagi pemikir logo sentris yang meletakkan simbol, ritual, tradisi sebagai sesuatu yang sudah final dan harus diikuti selama simbol, ritual, tradisi ini masih berada ditengah masyarakat.

Tetapi bagi Derrida, dekonstruksi tidak berhenti pada satu titik, melainkan bergerak dinamis membongkar kekakuan yang dimiliki suatu pemikiran. Derrida berfikir pasti ada tafsiran lain dari tafsiran yang sudah ada di balik sebuah simbol simbol. Makna lainnya itu yang sebenarnya dicari oleh dekonstruksi. Simbol, tulisan (teks) merupakan gambaran atau representasi dari ucapan (Murtiningsih, 2012, p. 232). Tulisan hanya sebatas pada susunan huruf-huruf melainkan terdapat penafsiran dan pemaknaan.

\section{METODE PENELITIAN}

Metode penelitian yang digunakan adalah kualitatif. Metode ini dipilih karena diperlukan upaya untuk menggali keterangan dari subjek penelitian untuk menemukan data, memperjelas fakta, dari permasalahan yang diangkat dalam penelitian ini. Karenanya diperlukan suatu upaya penelitian dan keterlibatan langsung peneliti di dalamnya untuk mengamati dari dekat dan mendalam. Seperti yang dikemukakan oleh Gorman and Clayton (2005:3) bahwa the key assumption made by qualitative researches is that the meaning of events, occurences and interactions can be understood only through the eyes of actual participants in specific situations.

Analisis di dalam penelitian ini adalah eksploratif-deskriptif-, yaitu mengeksplorasi pendapat, tanggapan, usulan dari berbagai pihak, serta mendeskripsikan hasil pengumpulan data yang didapat dari informan. Informan pada penelitian ini adalah para pustakawan IAIN Kudus dan UIN Walisongo Semarang. Waktu penelitian dimulai pada bulan Mei 2020 dan berlangsung secara insidental sesuai dengan kebutuhan perolehan data sampai dengan bulan Juli 2020. Lokus penelitian dipilih dari kriteria perpustakaan yang mempunyai pustakawan PNS dan secara kuantitas belum menulis secara produktif pada jurnal-jurnal ilmiah bidang perpustakaan.

Pengumpulan dalam penelitian ini menggunakan metode yang pertama adalah dengan observasi ke IAIN Kudus dan UIN Walisongo Semarang dengan melihat dan meneliti secara langsung objek penelitian mengenai kondisi, kejadian, fakta di lapangan. 
Dalam hal ini observasi dilakukan untuk mendapatkan data mengenai produktivitas pustakawan dalam menulis pada jurnal-jurnal ilmiah bidang perpustakaan terutama pada jurnal yang diterbitkan oleh instansi di bawah PTKIN.

Metode pengumpulan data yang kedua adalah wawancara. Pada wawancara ini peneliti menanyakan tentang masalah yang dihadapi ketika para informan (pustakawan) menyusun atau membuat karya tulis. Wawancara dilakukan dengan pertanyaan-pertanyaan terbuka melalui media WhatApp dan atau secara langusng bertemu dengan informan pada lokasi yang sudah disepakati antara kedua belah pihak. Alat bantu yang digunakan adalah draft pertanyaan dan alat bantu rekam berupa tape recorder, email, WhatsApp, maupun media lain.

\section{HASIL DAN PEMBAHASAN}

Pengembangan profesi pada Permenpan Nomor 09 Tahun 2009 menyantumkan regulasi tentang kewajiban seorang pustakawan dalam membuat karya tulis, baik berupa kajian teori maupun naskah dari hasil penelitian, hasil studi, hasil analisa maupun pengalaman lainnya Kegiatan penulisan ini diperuntukkan bagi semua jenjang pustakawan baik tingkat keterampilan maupun tingkat keahlian. Angka kredit untuk kegiatan ini pun tergolong paling besar di bandingkan kegiatan lain di dalam unsur utama.

Menulis menjadi media bagi pustakawan dalam menyampaikan buah pikirannya kepada orang lain. Sejalan dengan kode etik profesi pustakawan yang diperkuat dengan Undang-Undang Nomor 43 tahun 2007 dikatakan bahwa pustakawan adalah orang yang diberi tanggung jawab untuk mengembangkan perpustakaan. Hal tersebut memiliki arti bahwa pustakawan dengan segala kompetensi yang diperolehnya baik melalui pendidikan atau pelatihan bidang kepustakawanan, ia memiliki tanggung jawab moral melaksanakan pelayanan perpustakaan, pengorganisasian informasi (bahan pustaka) dan mengembangkan profesinya, salah satu cara pengembangan profesi ini adalah dengan menulis.

\section{Kompetensi Menulis Pustakawan PTKIN Era Sekarang}

Menulis menjadi bagian dari strategi pustakawan dalam menunjang karirnya di dunia kepustakawanan. Trend kompetensi pustakawan sekarang mengarah pada kemampuan pustakawan untuk membuat karya tulis. Data pilah sebagaimana disampaikan pada tabel 3, dari sejumlah jurnal bidang ilmu perpustakaan dan informasi di PTKIN, menunjukkan bahwa pustakawan PTKIN sudah mulai merambah pada dunia kepenulisan.

Observasi tentang pustakawan penulis dilakukan melalui sistem daring dari platform Online Journal System (OJS) masing-masing terbitan dalam bidang ilmu perpustakaan dan informasi. Untuk mempermudah proses penelusuran digunakan indeks jurnal nasional yang dikelola oleh Kementerian Agama RI, yaitu http://moraref.go.id. Sejumlah pustakawan PTKIN sudah menghasilkan berbagai artikel yang dipublikasikan. Melihat tiga edisi jurnal yang sudah diterbitkan secara online, memperkuat argumen 
bahwa pustakawan PTKIN sudah mulai bergerak keluar dari "zona aman" untuk membidangi tulis-menulis. Penulisan ini mengambil sampel dari tiga terbitan terakhir, karena terdapat jurnal perpustakaan yang dikelola PTKIN ini baru terbit dalam tiga edisi saja, sehingga dianggap cukup untuk sebagai representasi dari seluruh jurnal yang ada.

Jurnal Pustakaloka yang dikelola oleh IAIN Ponorogo sudah terbit dalam 10 volume, ini artinya sudah lima tahun diterbitkan, dan baru selama 2 tahun terakhir di terbitkan menggunakan Online Journal System (OJS). TIK ILMEU, jurnal yang dikelola oleh IAIN Curup, baru terbit sampai volume 2. Libraria yang dikelola IAIN Kudus sudah terbit dalam lima volume, ini artinya jurnal ini sudah berjalan selama kurang dari tiga tahun. JIPI, Jurnal yang dikelola oleh UIN Sumatera Utara juga telah menerbitkan sampai volume 3, atau baru berjalan tiga tahun. Pustabiblia yang diterbitkan IAIN Salatiga, juga baru terbit dalam dua volume tiga edisi, yang berarti baru terbit kurang dari dua tahun.

\section{Faktor pendukung dan penghambat kompetensi menulis pustakawan}

\section{a) Faktor pendukung}

Kompetensi menulis bagi pustakawan merupakan kompetensi yang perlu dikuasai oleh pustakawan. Menulis bisa menjadi media penyaluran aspirasi dan imajinasi pusakawan. Aktualisasi berbagai ide dan pemikiran sehingga menjadi ilmu pengetahuan dapat dituangkan dalam bentuk tulisan.

Kompetensi ini memerlukan dukungan baik dari segi regulasi maupun dari segi budaya. Faktor pendukung dari segi regulasi diantaranya adalah:

1) UU No. 43 Tahun 2007 tentang perpustakaan, memberikan peluang kepada pustakawan untuk menulis dalam berbagai format, tidak hanya dalam konteks karya ilmiah sebagai teks book, melainkan juga dalam bentuk terjemahan, alih dari suara, dan atau alih dari media lain (transmedia). Pada bab II pasal 7 Undang-Undang Nomor 43 Tahun 2007, disebukan bahwa pemerintah menjamin ketersediaan keragaman koleksi perpustakaan melalui terjemahan (translasi), alih aksara (transliterasi), alih suara ke tulisan (transkripsi), dan alih media (transmedia).

2) Perman RB Nomor 09 Tahun 2014 tentang Petunjuk Teknis Jabatan Fungsional Pustakawan dan Angka Kreditnya. Pada petunjuk teknisnya dikatakan bahwa pustakawan akang diperhitungkan angka kreditnya salah satunya dengan membuat Karya Tulis atau Karya Ilmiah hasil penelitian, pengkajian, survey dan evaluasi di bidang Kepustakawanan yang di publikasikan.

Dari dua struktur atau regulasi Undang-Undang Nomor 43 Tahun 2007 dan Permenpan RB Nomor 09 Tahun 2014 ini sudah cukup kuat memberikan rambu-rambu bahwa pustakawan mempunyai kewajiban menulis sebagai salah satu cara memenuhi capaian angka kredit guna kenaikan pangkat. 
Faktor pendukung kedua adalah dari faktor kultural atau budaya. Bahwa dalam masa perkembangannya, dunia kepenulisan bagi pustakawan telah terwadahi oleh berbagai wadah aspirasai, diantaranya adalah:

1) Terbitan Jurnal Ilmiah bidang Ilmu perpustakaan dan Informasi.

Pustakawan dalam jenjang karirnya memerlukan angka kredit yang diperoleh dari upaya pustakawan itu sendiri baik dengan mengerjakan pekerjaan sesuai dengan tupoksinya sebagai pustakawan, maupun dengan menulis. Karena kepentingan ini, jurusan bidang ilmu perpustakaan, asosiasi, mengambil inisiatif untuk membuat jurnal ilmiah yang naskah artikel yang diterbitkan menyentuh ide dan aspsirasi para pustakawan, baik untuk tingkat lokal, nasional maupun internasional. Penerbitan Jurnal ilmiah bidang perpustakaan, dokumentasi, dan informasi menjadi budaya yang sudah ada dan perlu dikembangkan sebagai wadah aspirasi intelektual para pustakawan.

2) Munculnya komunitas menulis pustakawan

Berbagai stimulus agar pustakawan berkemauan untuk menulis, telah dilakukan oleh berbagai kalangan dan salah satunya hadir dari Kelompok Menulis Pustakawan (KMP) yang aktif memberikan peluang bagi pustakawan di Indonesia untuk menuliskan ide, pikiran, dan curah gagasannya. KMP beranggotakan pustakawan dari seluruh Indonesia yang mempunyai peminatan dalam aktivitas menulis. KMP lebih general, tidak mengkhususkan pustakawan dalam jenis tertentu, melainkan pustakawan dari semua jenis baik dari Perguruan Tinggi, Pustakawan dari perpustakaan umum sampai pada pustakawan dari perpustakaan khusus.

KMP memfasilitasi para pustakawan untuk menerbitkan karya tulisnya dalam bentuk buku dalam genre antologi. Naskah artikel atau isi naskah buku yang diterbitkan oleh KMP berasal dari para pustakawan. Setiap penerbitan yang akan dilakukan, KMP memberikan informasi melalui group media sosial untuk sosialisasi ketentuan naskah. Pustakawan diundang untuk membuat karya tulis sederhana secara tematik yang ditentukan redaktur KMP, untuk kemudian tulisah yang dikirimkan akan diterbitkan dalam bentuk buku antologi. Dengan adanya kelompok menulis pustakawan ini, budaya menulis perlahan mulai dibentuk dan dipaksakan ada.

\section{b) Faktor Penghambat atau Kendala.}

Menulis membutuhkan pembiasaan. Menulis bukan hanya sekedar menjajarkan huruf-huruf menjadi kata. Juga bukan merangkai kata-kata yang terbentuk menjadi kalimat, atau bahkan tidak semata-mata menyusun berbagai kalimat menjadi paragraf dan seterusnya, melainkan perlu menhadirkan unsur seni di dalamnya, sehingga penikmat 
tulisan ini akan merasa nyaman dan mudah memahami apa yang tuangkan dalam naskah tersebut. Pustakawan PTKIN mulai merambah dunia tulis menulis ini sebagaimana di sampaikan pada bab sebelumnya.

Namun demikian, ada fakta menarik yang perlu digali lebih lanjut, yaitu mengenai kendala yang dihadapi ketika pustakawan ingin menulis. Pada beberapa kesempatan melakukan wawancara dengan informan menggunakan media daring kepada pustakawan target dari IAIN Kudus dan UIN Walisongo Semarang, diperoleh keterangan bahwa kesulitan dalam menulis yang dihadapi oleh pustakawan adalah sebagai berikut:

\section{a. Kekhawatiran Penjiplakan (Plagiat)}

Hal yang pertama sebagai kategori masalah yang dihadapi pustakawan dalam menulis karya ilmiah adalah kekhawatiran pustakawan bila terdeteksi plagiat. Berdasarkan tanggapan dari para informan. , diperoleh keterangan bahwa:

"Kalau bagi saya sih kendala menulis ini banyak, tapi kemudian ya tergantung individu maksudnya kita sendiri sih gimana cara mensikapi. Kalau saya cenderung dari faktor eksternal yaitu tentang aturan plagiarism. Maklum penulis pemula seperti saya ini kalau menulis ya harus melihat tulisan orang dulu dan saya ikuti. Tinggal ganti kasusnya aja. Kalimat banyak yang sama." (AF,18.s)

"Kalau menurut aku, kendala terbesar menulis itu malah plagiarism mas. iya sih sebenarnya kalau nulis sendiri tanpa jiplak kalimat orang lain sku kira aman. Tapi saya nyusun kalimat aja berantakan je...caranya ya ikut kalimat yang sudah ada aja. $(\mathrm{IW}, 18 . \mathrm{k})$

Disampaikan oleh informan jika zaman sekarang plagiat menjadi istilah yang populer dikalangan para penulis, dimana istilah ini sebisa mungkin dihindari dari titik praktisnya. Plagiat makin terkekang sebab ruang online dan dunia internet sudah mendeklarasi untuk memerangi segala jenis plagiarisme ini melalui mesin-mesin pemantau jiplakan (plagiarism checker).

Sebelum plagirism checker ini ada, tidak sedikit orang yang memiliki kemampuan menulis dengan mengandalkan metode copy-paste dari berbagai sumber. Hanya saja kaidah pengutipan dan etika sitasi kiranya belum dipedomani, sehingga tidak jarang ditemukan kasus jiplakan pengutipan tanpa menyebut sumber aslinya. Dan ternyata sanksi hukum untuk pelaku yang demikian menyebabkan penulis menjadi ketakutan untuk selalu produktif kembali.

\section{b. Kurangnya Aktivitas Membaca}

Menulis merupakan bahasa lain dari cara menuangkan gagasan selain lisan. Semakin banyak materi yang dikuasai, pembicaraan akan semakin panjang dan secara substansi juga akan lebih berkualitas. Singkat kata, menulis sangat tergantung dari materi yang dikuasai. 
Semakin banyak materi yang dimiliki, semakin memudahkan menuangkannya dalam sebuah tulisan. Kategori kedua tentang masalah menulis yang dihadapi pustakawan adalah kurangnya aktivitas membaca, sebagaimana hasil wawancara berikut:

"Kendala yang cukup berat dalam menulis menurut saya kurangnya materi atau bahan bacaan. Lha kita mau nulis apa kalau bahannya saja tidak ada. Penjahit itu akan menjahit apa kalau kainnya saja tidak tersedia. Maksud kurang bahan disini bukan pustakawan kekurangan buku, sebaliknya justru pustakawan berlebih stok buku untuk dibaca. Saya menyadari sih mas, saya sangat kurang kalau ditanya tentang aktivitas membaca." (YW,19.k).

Menanggapi dari pertanyaan mengapa kurang membaca referensi, dikatakanya bahwa :

"Kesibukan rutinitas teknis di perpustakaan membuat waktu untuk membaca ini sepertinya sedikit bahkan mungkin tidak ada. Jangankan membaca referensi, membaca karya fiksi saja seperti tidak ada waktu lagi”. (YW, 19.k)

Ketika ditanya tentang tugas rutin apa yang membuatnya menyita waktu, informan YW memberikan keterangan bahwa:

"Pengolahan ini cukup buat saya repot mas. pengolahan buku ini seperti tanpa ada selesainya, pas sepertinya sudah selesai mengerjakan satu pengolahan, datang kembali koleksi yang perlu diolah, begitu seterusnya. Jadi ya nikmatin aja tugasku di pengolahan. (YW, 19.k)

Dari keterangan YW disimpulkan bahwa pekerjaan teknis, khususnya di pengolahan membuat YW mempunyai waktu yang minimal untuk menulis. Sehingga dari faktor ini menjadi kendala pustakawan untuk membaca karya ilmiah maupun membaca buku lain yang membutuhkan waktu. Karena hal ini, sekaligus berefek pada menghambat pustakawan menguasai bahan bacaan sebagai referensi dalam menulis.

Begitu pula dengan RZ yang memberikan keterangan yang senada dengan YW bahwa disadarinya jika menulis yang baik adalah menggunakan bahan referensi yang sesuai dan memadai. Karena bahan bacaan atau referensi yang dimilikinya kurang memadai, maka kekurangan referensi ini menjadikan kendala baginya untuk menulis. Alasan kekurangan referensi nyaris sama, yaitu karena pekerjaan rutin yang menyita waktu sehingga waktu untuk membaca sangat dipengaruhi oleh kegiatan rutin

Membaca, mendengar, merasa adalah aktivitas yang saling mendukung untuk menjadi bahan pada aktivitas menulis. Dengan membaca akan diperoleh banyak informasi dan wawasan, dengan mendengar akan menggerakkan otak kanan untuk berfikir dan 
menyusun informasi yang diterima, dan dengan merasa akan diperoleh keindahan dalam berperilaku dan dalam menentukan keputusan. Karenanya membaca merupakan salah satu cara meng-updateilmu dan wawasan.

\section{c. Kesulitan Menentukan Topik}

Menulis dengan berbicara verbal adalah jenis komunikasi yang hanya dibedakan oleh bentuk media saja. Jika berbicara medianya oral, maka menulis menggunakan media alat tulis. Keduanya bergantung pada materi (topik) pesan.

Topik adalah inti masalah yang akan dijadikan bahan kajian atau uraian. Karenanya topik adalah komponen pokok pada kegiatan menulis. Namun demikian justru menentukan topik ini seringkali menjadi masalah dalam menulis.

"Saya ini seneng sebenarnya kalau disuruh menulis. Tapi yang bikin saya galau itu kalau sudah disuruh menentukan topiknya. Nah kalau sampeyan tanya soal kendala menulis apa, ya itu hal yang paling saya rasakan adalah memilih topik. Tapi kalau udah udah ketemu and mood, Insya Allah lancar nulisnya.' (AF,20.1).

“Di dunia tulis-menulis, jujur saya itu sering punya kendala gagal fokus di penentuan topik. Kadang mau memulai dari mana itu saja sering ya-tidak, tulis-jangan. Saya gak tahu apakah berawal dari gagal fokus di topik tadi atau punya topik tapi ide tidak berjalan mulus pada saat perjalanan menulis. Seringkali terjadi stag ketika sudah mulai kehilangan mood.”(DW,20.k).

Napas utama sebuah tulisan adalah pada topik. Setiap paragraf atau lebih luas lagi adalah alinea, memerlukan topik yang akan dibahas. Biasanya penulis akan kehilangan topik manakala pikiran sudah penat dan tidak lagi fokus pada keinginannya untuk menulis. Maksudnya adalah seseorang bisa saja memiliki ide yang melimpah, tetapi terkadang untuk menuliskan satu ide saja yang akan menjadi objek bahasan, justru kebingungan memilih diantara ide yang bertebaran. Bukan salah idenya yang banyak, bukan pula topiknya yang sulit, akan tetapi lebih pada kondisi psikologis yang bersangkutan, diantaranya persoalan perspektif.

Biasanya kasus seperti itu kurang terbiasanya pikiran mengorganisasikan ide. Ini seperti yang diungkapkan Lopatina pada masa awal munculnya internet memberi peluang kepada siapa saja tentang kemudahan mengakses informasi (Lopatina, 2014). Namun sejalan dengan perkembangannya, informasi yang disalurkan melalui internet jumlahnya tidak lagi terbendung dan berproduksi dalam waktu yang cukup singkat. Dari sini orang mulai kewalahan mencari dan menentukan informasi yang paling relevan, kecuali dengan menggunakan strategi tertentu.

Hal yang bisa dilakukan untuk mengatasi kesulitan menentukan topik atau ide ini adalah membangun ketertarikan terhadap objek bahasan. Pustakawan era sekarang mulai 
bergeliat dengan berbagai kegiatan, menghadiri undangan-undangan seminar, FGD (Forum Group Discussion), lokakarya, dan atau pertemuan-pertemuan lainnya. Dengan berbagai kegiatan ini informasi baru, ketertarikan terhadap suatu objek bisa ditanamkan. Dalam satu tahun anggaran, banyak pelatihan atau workshop yang bertemakan kepustakawanan. Tentu informasi terdapat perkembangan informasi dari kegiatan ini yang bisa dilanjutkan dengan mengembangkan pemikiran atau ide ke dalam sebuah tulisan.

\section{d. Terjebak Dalam Pekerjaan Teknis}

Time is money, sebuah pepatah lama yang memberikan tempat yang penting bagi waktu, dimana diasumsikan waktu adalah sesuatu yang berharga sampai-sampai diibaratkan waktu adalah uang. Pun demikian dengan penyediaan waktu untuk menulis.

"Kendala menulis menurut saya karena alasan sibuk dengan pekerjaan teknis, sehingga kesempatan menulis menjadi sempit. Belum lagi menulis ini bukan menjadi bagian pekerjaan pokok pustakawan, jadi yang mau menulis silahkan, tidak mau juga tidak ada sanksinya. Hanya saja jika mau menulis, perolehan angka kredit untuk kenaikan pangkat, bisa didapat lebih besar dari unsur utama lainnya setelah pendidikan formal."(DW,21.k)

“Kalau ditanya soal kendala menulis, saya lebih banyak terkendala karena pekerjaan rutin yang menjadi tanggung jawab saya. Ketika saya mengerjakan pekerjaan rutin, ya selesai tugas-tugasnya lebih dahulu, menulis bisa dikerjakan sambil lalu. (FA,21.1)

Alasan seseorang sulit menulis diantaranya adalah sibuk dengan aktivitas yang menyingkirkan waktu untuk menulis, atau memang waktu yang sudah diplot untuk pekerjaan dan lain-lain, belum dialokasikan untuk kegiatan menulis. Setiap manusia diberi waktu yang sama oleh Tuhan sejumlah 24 jam setiap harinya. Kemudian memasrahkan kepada manusia untuk memanfaatkan waktu itu dengan sungguh-sungguh dan sebaikbaiknya, dan menjadikan waktu itu sebagai kesempatan untuk secara bertahap menjadikan dirinya memiliki keunggulan, termasuk salah satunya adalah bidang penulisan.

\section{e. Malas}

Penyakit yang sering menjangkiti para penulis agar senantiasa produktif adalah rasa malas.

"Kata malas itu kayanya lebih pas dijadikan alasan kenapa orang tidak menulis. Saya sendiri kalau sedang malas memang mau berbuat apa gitu sudah tidak bersemangat. Padahal kunci membunuh malas itu hanya semangat.”(YW,22.k) 
“Menulis ini perlu komitmen dan keberanian bertindak. Rasa malas yang kadang datang, ini yang membuat saya merasa harus mengubur keinginan berbagi ide. Betapa tidak, kalau rasa malas sudah datang, jangankan menulis yang membutuhkan waktu dan energi, hanya sekedar ngobrol saja itu masih belum menganulir malas saya."(DW,22.k)

Malas bukan larangan manakala badan memang membutuhkan relaksasi dan terbebas dari gangguan pekerjaan. Malas dalam konteks ini adalah memberikan jatah istirahat tubuh agar segera bisa sehat kembali. Malas ini lebih dominan karena faktor psikologis. Dekonstruksi mengajak berfikir dari hal-hal yang tidak mungkin menjadi memungkinkan, berfikir dari hal-hal yang tidak terjangkau menjadi terjangkau (Critchley et al., 2003, p. 2). Perasaan puas, nyaman, tidak mau bergerak, dan semacamnya ini yang menjadikan sistem pikir yang tidak mau berubah. Hal demikian perlu didekonstruksi dengan cara berbuat sesuatu yang lain yang bisa membuat produktif kembali.

\section{f. Merasa Tidak Memiliki Bakat Dalam Menulis}

Seringkali orang mengasumsikan bahwa untuk bisa melakukan sesuatu diperlukan bakat. Untuk bisa membengkel, service sepeda motor, mobil dan lain-lain alat otomotif diperlukan bakat. Untuk bisa menari, menyanyi dan aktivitas lain diperlukan talenta, pun demikian dengan menulis.

"Dulu saya pernah beranggapan untuk nulis itu perlu bakat. Orang yang tidak punya bakat menulis, akan sulit menemukan cara menulis. Sebaliknya orang yang punya bakat akan mudah menemukan strategi menulis. Saya kira ini juga pernah terpikir oleh orang lain yang dituntut harus menulis, tetapi tidak selesai. Atau bisa mengerjakan tetapi penuh dengan keterpaksaan”(DW,23.k).

Hamka pernah menyindir dalam sebuah tulisannya, bahwa orang yang selalu merasa takut dan khawatir (termasuk beralasan tidak punya bakat), sesungguhnya sedang dibelenggu oleh alasan-alasan, dan tidak pernah melakukan sesuatu. Setiap individu memiliki potensi yang berbeda dengan individu lain, bergantung pada lingkungan sekitar yang membentuknya.

John Locke menyebut konsep tabularasa pada diri manusia. Menurutnya manusia lahir dalam keadaan seperti kertas putih. Akan berada di posisi mana, bergantung pada warna yang diberikan pada kertas putih itu. Lingkungan sekitar yang terdekata dengannya berpotensi memberi warna dominan kepada kertas putih itu. Artinya bakat manusia itu tidak tercipta dari masa dia lahir, melainkan dibentuk oleh individu itu sendiri bersama lingkungan yang mempengaruhinya. 


\section{g. Tidak Percaya Diri}

Nurkholis Madjid dalam salah satu tulisannya sempat menyindir halus tentang ketidakpercayadirian seseorang memulai suatu pekerjaan. "Orang itu boleh memiliki sifat sombong, sebatas untuk meningkatkan harga dan kepercayaan diri”. Cak Nur, sapaan akrab Nurkholis Madjid ini menggungah motivasi agar orang segera keluar dari belenggu kekhawatiran terhadap diri sendiri. Saat menulis ada kekhawatiran "jangan-jangan": Jangan-jangan tidak tepat menuliskan ini, jangan-jangan kurang bagus kalau mengawali menulis seperti ini, dan sebagainya.

“Kendala saya pertama kali dalam kegiatan "menulis" ini adalah tidak percaya diri. Apalagi saya pernah beberapa kali di tolak oleh surat kabar. Saya sering berfikir kalau tulisan saya ini tidak mutu, tidak bagus, malah sering bertanya layak tidaknya untuk dibaca. Tapi lama kelamaan saya nekat aja, kirim sana-sini, ke beberapa surat kabar di sini. Prinsip saya sih, masa iya dari sekian kali kirim tidak ada satupun yang bisa diterima. Lah..malah akhirnya ada juga ternyata yang mau menerima tulisan saya. Saya punya strategi untuk mengawali menulis itu saya menggunakan alat bantu yaitu menuliskan awal kalimat dengan menyajikan kata pada tema yang akan ditulis pada keseluruhan naskah. Misalnya ingin menulis dengan tema "Perpustakaan dan literasi" maka baris awal yang bias saya tulis adalah menyebut perpustakaan untuk dikembangkan pada narasi selanjutnya, atau menyebut literasi terlebih dahulu pada awal baris yang akan dijelaskan pada barisbaris berikutnya. "(FA,24.1)

Dari informasi yang disampaikan oleh informan penelitian ini, rasa tidak percaya diri seringkali menjangkiti psikologis pustakawan dalam menulis. Ketika perasaan itu muncul, secara berkelanjutan mempengaruhi daya juang melahirkan tulisan. Kekhawatiran tulisannya tidak bermutu, takut tidak diterima oleh media, takut dianggap tidak berkualitas oleh pembaca adalah hal yang sering menjadi pertimbangan ketika akan mulai menulis.

Sebagai seorang penulis membangun kepercayaan diri ini menjadi penting mengingat apa yang akan dituangkan membutuhkan keyakinan bahwa informasi yang dituangkan dalam naskah adalah informasi yang bermanfaat bagi pembaca. Krizner dan Mandel juga menyinggung bahwa menulis ini perlu berfikir siapa calon pembacanya (audien) (Kirszner \& Mandell, 2008, p. 9). Modal percaya diri bisa menumbuhkan semangat mencari referensi dan mengemas bahasa narasi yang mudah dipahami dan sekaligus penulis mampu menyuguhkan tulisan dengan substansi yang bermutu dan dapat diterima oleh pembacanya.

\section{h. Lingkungan yang Tidak Mendukung}

Lingkungan sebagai tempat berinteraksi, bersosialisasi, dan berkomunikasi mempunyai pengaruh yang besar terhadap pola pikir dan identitas individu. lingkungan yang baik akan memberikan support positif kepada siapa saja yang ada di dalamnya, 
sebaliknya lingkungan yang negatif, tidak memberikan kontribusi dukungan. Di dalam menulis pun ternyata tidak lepas dari peran lingkungan di sekitarnya.

"Hambatan saya dalam menulis salah satunya memang lingkungan yang tidak mendukung mas. maksud saya, ada aja sih orang yang tidak suka saya berkreasi dalam hal ini menulis. Tapi anehnya justru datang dari kalangan seprofesi kita. Ya memang sih sebenarnya kembali ke kitanya, kalau kitanya siap, dan tidak peduli dengan lingkungan sekitar sih fine-fine aja. Tapi apa kita mampu menghindar dari lingkungan kita sendiri, kan gitu. Tetep saja hal yang seperti itu menurut saya sebagai faktor penghambat juga." (FA,26.1)

Hal ini sempat disinggung oleh John Locke dengan konsep tabularasanya bahwa manusia ini layaknya kertas putih, bergantung kepada lingkungan yang akan memberikan warna terhadap manusia yang ada di dalamnya. Manusia sebagai makhluk sosial tidak akan bisa lepas dari pengaruh lingkungannya. Sebagaimana yang diutarakan Sigmun Freud tentang superego bahwa manusia akan melihat nilai baik atau buruk karena ada kesepakatan dari lingkungan tentang nilai-nilai tersebut. Menurut pemikiran ini sangat mungkin lingkungan sebagai objek kebenaran yang akan menjadi model untuk perkembangan individu selanjutnya.

\section{i. Angka Kredit Rendah}

Kenaikan pangkat dan jenjang jabatan bagi seorang pegawai baik untuk pegawai swasta maupun pegawai negeri adalah sebuah prestasi. Bagi pustakawan, kenaikan pangkat atau jabatan bisa dikatakan sebagai apresiasi terhadap pegawai yang sudah mengabdi dan bekerja dengan baik. Bagi pustakawan ukuran prestasi kerja yang bisa dihitung dengan angka sudah diatur dalam Peraturan Menteri Pemberdayaan Aparatur Negera (Permenpan) No. 09 Tahun 2014 tentang Jabatan Fungsional Pustakawan dan Angka Kreditnya.

Pada penelitian ini diperoleh informasi dari beberapa informan terkait dengan kesulitan pengembangan profesi bidang karya tulis sebagai berikut:

“Beruntung saya tidak peduli dengan jumlah angka kredit yang diberikan pak. Maksud saya, saya tidak telalu mikirin kerja ini dapat angka berapa, kerja itu dapat angka berapa, gitu. Bagi saya yang terpenting adalah berkarya. Memang kalau mikir ini saya juga menjadi kurang bergairah. Sekarang coba bapak renungkan, untuk karya tulis jadi yang berupa buku, nilai maksimal hanya 12.5. makalah yang diterbitkan, nilai maksmal 6. Sedangkan untuk makalah yang tidak dipublikasikan dihargai sekita 2 s.d 2.5. Saya menduga dan mengalami sendiri, kalau melihat perolehan yang kecil ini, saya menjadi tidak semangat.”(AF,28.s)

"Iya sih mas wiji, saya sendiri kadang juga melirik permenpan no 09 Tahun 2014 ini tidak memihak, meskipun saya yakin juga UU ini dibuat juga melalui diskusi panjang. Tidak memihaknya karena membandingkan juga dengan fungsional dosen 
yang angka kredit kegiatannya lumayan besar. Lah di pustakawan angka kreditnya enol koma, itupun masih ada nol-nol lagi di belakang komanya. Hehehehe." (RZ,28.s).

Jadi kesulitan pustakawan dalam menyusun karya tulis bukan saja muncul dari dalam dirinya saja, melainkan juga faktor eksternal, salah satu diantaranya adalah dari perolehan angka kredit yang di atur dalam undang-undang. Dalam konsep psikologis dijelaskan bahwa dorongan yang menguntungkan menjadi motivasi seseorang untuk melakukan tindakan. Artinya jika angka kredit ini menguntungkan bagi pustakawan, dalam hal ini pada poin karya tulis, akan menjadi titik dorong pustakawan untuk lebih produktif lagi dalam menulis.

Motivasi yang dimaksud ini adalah alasan atau sesuatu hal yang mendasari gairah untuk melakukan suatu tindakan. Jika pada konteks pekerjaan itu ada reward dan punishment sebagai bentuk strategi pengembangan sumber daya manusia, maka pada konsep ini angka kredit yang menguntungkan adalah sebagai reward positif yang menimbulkan suatu dorongan untuk tetap melakukan hal yang sama atau bahkan lebih baik lagi.

Tidak saja terbatas pada bidang karya tulis, pada unsur utama lainnya pun demikian. Bandingannya adalah Juknis angka kredit dosen yang angka perolehannya jauh lebih besar dari pustakawan. Satu contoh untuk buku, dosen bisa mencapai angka maksimal 40 dan terendah 20, sementara pustakawan menulis buku jumlah angka kredit maksimal 12,5 dan bahkan bisa hanya dihitung sampai angka 8 saja. Kesenjangan ini menjadi salah satu faktor kesulitan pustakawan dalam menghasilkan karya tulis.

Pengembangan profesi pustakawan dalam Permenpan No. 09 Tahun 2014 tentang Jabatan fungsional pustakawan dan angka kreditnya berkutat pada bidang karya tulis, baik itu buku, makalah, artikel, sampai pada pembuatan abstrak. Pengembangan profesi ini dirinci dalam beberapa detail kegiatan penulisan. Hal inilah sebenarnya yang menjadi keluhan pustakawan selama ini. Angka kredit yang kecil dibanding dengan angka kredit dosen dalam hal karya ilmiah, dan mengakibatkan keenganan menulis menjadi titik kritisi informan pada khususnya dan para pustakawan PTKIN pada umumnya, agar permenpan ini bisa lebih akomodatif terhadap kepentingan profesi pustakawan. Konkritnya, angka kredit untuk pustakawan perlu direvisi dan disesuaikan dengan kondisi saat ini.

\section{SIMPULAN}

Sebagai penutup dapat disampaikan suatu kesimpulan bahwa pertama, pustakawan PTKIN, khususnya pustakawan IAIN Kudus dan UIN Walisongo sudah menunjukkan performa di bidang penulisan karya ilmiah, dibuktikan dengan terbitnya berbagai media penerbitan karya ilmiah. Kedua, Pustakawan IAIN Kudus dan UIN Walisongo melihat beberapa faktor pendukung kompetensi menulis pustakawan adalah dari faktor regulasi 
dan budaya. Ketiga, Pustakawan IAIN Kudus dan UIN Walisongo melihat faktor penghambat kompetensi menulis pustakawan adalah kekhawatiran plagiat, kurangnya aktivitas membaca, kesulitan menentukan topik, terjebak dalam pekerjaan teknis, malas, merasa tidak mempunyai bakat menulis, tidak percaya diri, lingkungan yang tidak mendukung, merasa miskin referensi, dan angka kredit yang rendah.

Saran yang dapat penulis berikan untuk perkembangan komptensi para pustakawan baik di IAIN Kudus dan UIN Walisongo maupun secara luas untuk para pustakawan di Indonesia agar diberikan ruang dalam kegiatan penulisan maupun penelitian, penulis merekomendasikan untuk dilakukannya perubahan juknis penentuan angka kredit pustakawan perlu direvisi dalam hal pemberian angka kredit yang menyesuaikan dengan beban kerja pustakawan.

\section{Kontribusi Pada Keilmuan}

Penelitian ini merupakan kajian dalam bidang Ilmu Perpustakaan. Penelitian ini juga berkaitan dengan bidang atau keilmuan manajemen sumber daya manusia atau human resource. Hasil penelitian ini dapat menjadi penelitian selanjutnya atau penelitian bidang sejenis mengenai bagaimana mengelola sumber daya manusia yang ada di perpustakaan dan lembaga informasi lainnya. Penelitian ini juga dapat menjadi sumber inspirasi bagi peneliti di bidang lain yang berhubungan dengan topik yang dibahas.

\section{Pernyataan Minat Kajian}

Peneliti bernama Wiji Suwarno memiliki minat kajian dalam bidang kepustakawanan

\section{Kontribusi Peneliti}

Peneliti dengan nama Wiji Suwirno melakukan wawancara, observasi dan dokumentasi dengan melakukan analisis data secara eksploratif-deskriptif-, yaitu mengeksplorasi pendapat, tanggapan, usulan dari berbagai pihak, serta mendeskripsikan hasil pengumpulan data yang didapat dari informan.

\section{DAFTAR PUSTAKA}

Coelho, F. (2011). Academic writing development through dialogues between tutors and second-language learners. Master's Theses. https://scholarworks.sjsu.edu/etd_theses/3915

Critchley, S., Derrida, J., Laclau, E., \& Rorty, R. (2003). Deconstruction and pragmatism. London: Routledge.

Foster, J. (2005). Effective writing skills for public relations (3rd ed). London : Kogan Page Limited.

Indonesia, D. R. (2014). Permenpan No.09 Tahun 2014 Tentang Jabatan fungsional pustakawan dan angka kreditnya. Jakarta: DPR RI.

Indonesia, D. T. K. (2008). Penulisan karya ilmiah. Jakarta: Direktorat Jenderal 
Peningkatan Mutu Pendidik Dan Tenaga Kependidikan.

Indonesia, K. R., Teknologi dan Pendidikan Tinggi. (2017). Peraturan Menteri Riset, Teknologi dan Pendidikan Tinggi Republik Indonesia Nomor. 20 Tahun 2017 Tentang Pemberian Tunjangan Profesi Dosen dan Tunjangan Kehormatan Profesor. Jakarta: Kemenristekdikti.

Kirszner, L. G., \& Mandell, S. R. (2008). The wadsworth handbook (8th ed). California: Wadsworth.

LiPuma, K. F. (2016). The influence of students' perceptions of writing on academic writing performance. New York: Department of Language, Learning and Leadership State University of New York.

Lopatina, N. V. (2014). The modern information culture and information warfare. Scientific and Technical Information Processing, 41(3), 155-158. Retrieved from https://link.springer.com/article/10.3103/S0147688214030034

Maksum, A. (2008). Pengantar filsafat: Dari masa klasik hingga postmodernisme. Yogyakarta: Ar-Ruz Media.

Murtiningsih, W. (2012). Para filsuf dari Plato sampai Ibnu Bajjah. Yogyakarta: IRCiSoD.

Nasihudin, W. (2017). Pustaka pengetahuan bidang kepustakawanan: LIS Journal. Retrieved from https://pustakapusdokinfo.wordpress.com/lis-journal/

Ritchie, B. (2015). Writing into the apocalypse an examination of the method of writing into the dark within the context of post-apocalyptic fiction: An exegesis (Tesis). Retrieved from https://ro.ecu.edu.au/theses/1739/

Wright, P. M., McMahan, G. C., \& McWilliams, A. (1994). Human resources and sustained competitive advantage: A resource-based perspective. International Journal of Human Resource Management, 5(2), 301-326. https://doi.org/10/1080/09585199400000020 
